\title{
Crystal chemistry and Raman spectroscopy of momoiite from Japan
}

\author{
Shunsuke ENDO* ${ }^{*}$ Mariko NAGASHIMA ${ }^{* *}$ and Masaki ENAMI ${ }^{* * *}$ \\ ${ }^{*}$ Department of Earth Science, Interdisciplinary Faculty of Science and Engineering, Shimane University, Matsue 690-8504, Japan \\ ${ }^{* *}$ Graduate School of Sciences and Technology for Innovation, Yamaguchi University, Yamaguchi 753-8512, Japan \\ ${ }^{* * *}$ Institute for Space-Earth Environmental Research, Nagoya University, Nagoya 464-8601, Japan
}

\begin{abstract}
Momoiite, a $\mathrm{Mn}^{2+}$ - and $\mathrm{V}^{3+}$-dominant member of the garnet group, has been reported from metamorphosed manganese deposits in Japan. Near end-member momoiite $\left(\mathrm{Mn}_{3} \mathrm{~V}_{2} \mathrm{Si}_{3} \mathrm{O}_{12}\right)$ has not yet been found in nature, and the chemical composition of natural momoiite is written as $(\mathrm{Mn}, \mathrm{Ca})_{3}(\mathrm{~V}, \mathrm{Al})_{2} \mathrm{Si}_{3} \mathrm{O}_{12}$, which represents intermediate compositions in solid-solution series between spessartine and Mn-rich goldmanite. Single-crystal X-ray diffraction data were obtained for an optically isotropic momoiite crystal from the Fujii mine, Fukui Prefecture, Japan. Structural refinement in the $I a \overline{3} d$ space group converged to $R_{1}=1.45 \%$, and the lattice constant is $a=$ 11.8745(7) $\AA(Z=8)$. The refined structural formula is ${ }^{\mathrm{X}}\left(\mathrm{Mn}_{1.763} \mathrm{Ca}_{1.237}\right)_{\Sigma 3.000} \mathrm{Y}\left(\mathrm{V}_{1.461} \mathrm{Al}_{0.539}\right)_{\Sigma 2.000}{ }_{\mathrm{Z}} \mathrm{Si}_{3} \mathrm{O}_{12}$, which is consistent with electron microprobe analysis. Raman spectra of the solid-solution series between spessartine and Mn-rich goldmanite show continuous change in peak positions. The $\mathrm{Si}-\mathrm{O}$ stretching and $\mathrm{O}-\mathrm{Si}-\mathrm{O}$ bending vibrations show downward frequency shifts with decreasing $\mathrm{Mn} /(\mathrm{Mn}+\mathrm{Ca})$ and increasing $\mathrm{V} /(\mathrm{V}+\mathrm{Al})$, which are associated with increase in mean ionic radii in the $\mathrm{X}$ and $\mathrm{Y}$ sites. The Al-V substitution controls the frequency shifts of the $\mathrm{O}-\mathrm{Si}-\mathrm{O}$ bending vibrations much more effectively than the $\mathrm{Mn}-\mathrm{Ca}$ substitution. In contrast, the frequency shift of the $\mathrm{SiO}_{4}$ rotation mode shows strong correlation with the $\mathrm{Mn}-\mathrm{Ca}$ substitution and is apparently independent on the Al-V substitution. This behavior suggests that the rotation of the $\mathrm{SiO}_{4}$ tetrahedron is strongly influenced by sharing two edges with $\mathrm{XO}_{8}$-dodecahedra. Crystal-chemical and Raman spectroscopic data of natural momoiite are consistent with those expected as an intermediate composition in the solid-solution series.
\end{abstract}

Keywords: Crystal chemistry, Garnet, Momoiite, Raman spectroscopy, Solid-solution

\section{INTRODUCTION}

Momoi (1964) first reported a Mn-rich variety of goldmanite (Gdm: $\mathrm{Ca}_{3} \mathrm{~V}_{2} \mathrm{Si}_{3} \mathrm{O}_{12}$ ) from the Yamato mine, Kagoshima Prefecture (Japan), and proposed $\mathrm{Mn}^{2+}$ analog of goldmanite as a hypothetical garnet end-member. $\mathrm{Mn}^{2+}$ - and $\mathrm{V}^{3+}$-dominant silicate garnet was later described by Tanaka et al. (2010), and this new garnet species was named as momoiite (Mom: $\mathrm{Mn}_{3} \mathrm{~V}_{2} \mathrm{Si}_{3} \mathrm{O}_{12}$ ). To date, momoiite has only been reported from four localities of metamorphosed manganese deposits in Japan: the Kurase mine in Ehime Prefecture (type locality), the Fujii mine in Fukui Prefecture, Hokkejino in Kyoto Prefecture (Tanaka et al., 2010) and the Tanohata mine in Iwate Prefecture (Matsubara et al., 2010).

doi: $10.2465 /$ jmps. 190219

S. Endo, s-endo@riko.shimane-u.ac.jp Corresponding author
All of the reported $\mathrm{Mn}^{2+}$ - and $\mathrm{V}^{3+}$-bearing garnet fall in a compositional trend evolving from spessartine through $(\mathrm{Mn}, \mathrm{Ca})_{3}(\mathrm{~V}, \mathrm{Al})_{2} \mathrm{Si}_{3} \mathrm{O}_{12}$ momoiite to $\mathrm{Mn}$-rich goldmanite. Two major compositional variables of the solid-solution series are $\mathrm{Mn}-\mathrm{Ca}$ substitution in the dodecahedral X site, and Al-V substitution in the octahedral Y site. Therefore, near end-member momoiite has not been found in nature. Based on the occurrence and crystalchemical consideration, Tanaka et al. (2010) suggest that the formation of near end-member momoiite requires ultrahigh-pressure conditions. End-member momoiite has been synthesized at $5 \mathrm{GPa}$ and $1000^{\circ} \mathrm{C}$, but experimental run at $2 \mathrm{GPa}$ and $1000{ }^{\circ} \mathrm{C}$ in the same chemical system produced vuorelainenite $\left(\mathrm{MnV}_{2} \mathrm{O}_{4}\right)$ and $\mathrm{Mn}$ pyroxenoid $\left(\mathrm{MnSiO}_{3}\right)$ instead of momoiite (Fursenko, 1983). The reaction limiting the low pressure end of the momoiite stability is written as: 


$$
\mathrm{Mn}_{3} \mathrm{~V}_{2} \mathrm{Si}_{3} \mathrm{O}_{12}=\mathrm{MnV}_{2} \mathrm{O}_{4}+2 \mathrm{MnSiO}_{3}+\mathrm{SiO}_{2}
$$

Although further experimental studies are necessary to bracket this reaction, end-member momoiite is obviously a high-pressure garnet.

Novak and Gibbs (1971) established crystal chemistry of six common garnet end-members, pyrope (Prp: $\mathrm{Mg}_{3} \mathrm{Al}_{2} \mathrm{Si}_{3} \mathrm{O}_{12}$ ), almandine (Alm: $\mathrm{Fe}_{3} \mathrm{Al}_{2} \mathrm{Si}_{3} \mathrm{O}_{12}$ ), spessartine (Sps: $\mathrm{Mn}_{3} \mathrm{Al}_{2} \mathrm{Si}_{3} \mathrm{O}_{12}$ ), grossular (Grs: $\mathrm{Ca}_{3} \mathrm{Al}_{2} \mathrm{Si}_{3} \mathrm{O}_{12}$ ), andradite (Adr: $\mathrm{Ca}_{3} \mathrm{Fe}_{2}^{3+} \mathrm{Si}_{3} \mathrm{O}_{12}$ ) and uvarovite (Uv: $\left.\mathrm{Ca}_{3} \mathrm{Cr}_{2} \mathrm{Si}_{3} \mathrm{O}_{12}\right)$. Crystallographic data of natural momoiite have only been reported for a sample from the Kurase mine by powder X-ray diffraction method (Tanaka et al., 2010). Crystal structure of goldmanite has been refined to be the $I a \overline{3} d$ space group as with the other silicate garnets (Novak and Gibbs, 1971; Righter et al., 2011), but structural refinement of momoiite has not been performed to date.

Raman spectroscopy is also an important tool to characterize garnet. Raman spectra of six common garnets, Prp, Alm, Sps, Grs, Adr, and Uv, have been studied thoroughly on the end-member (Hofmeister and Chopelas, 1991; Kolesov and Geiger, 1998) and also on intermediate compositions (Kolesov and Geiger, 1998; Pinet and Smith, 1993, 1994). However, Raman spectra of $\mathrm{V}^{3+}$-bearing garnet has not been studied in detail. Several attempts has been made to empirically formulate garnet compositions as a function of Raman spectral parameters (e.g., Bersani et al., 2009). Such works are worth for nondestructive characterization of microscopic garnet, which is applicable to various occasions including analysis of experimental run products.

Natural momoiite solid-solutions provide a valuable opportunity to examine crystal-chemical and vibrational spectroscopic behaviors of solid-solutions between noncalcic garnet (pyralspite) and calcic garnet with transition metals in the Y site (ugrandite). In the present study, we first conduct single-crystal $\mathrm{X}$-ray diffraction study of momoiite to refine its crystal structure. In addition, we report Raman spectra of garnet solid-solutions in the Sps-Grs-Mom-Gdm system at ambient conditions, with the aim of extending our knowledge on Raman spectra of silicate garnet to $\mathrm{V}^{3+}$-baring system.

\section{SAMPLE DESCRIPTION AND GARNET CHEMISTRY}

Garnet compositions were determined using a JEOL JXA-8900R electron microprobe at Nagoya University. Operating conditions were WDS mode, $15 \mathrm{kV}$ accelerating voltage, $12 \mathrm{nA}$ specimen current, and 2-3 $\mu \mathrm{m}$ beam diameter. The following materials were used as standards:
$\mathrm{SiO}_{2}(\mathrm{Si} K \alpha), \quad \mathrm{TiO}_{2}(\mathrm{Ti} K \alpha), \quad \mathrm{Al}_{2} \mathrm{O}_{3}(\mathrm{Al} K \alpha), \quad \mathrm{Cr}_{2} \mathrm{O}_{3}(\mathrm{Cr} K \alpha)$, $\mathrm{Ca}_{2}\left(\mathrm{VO}_{4}\right)_{2}(\mathrm{~V} K \alpha)$, hematite $(\mathrm{Fe} K \alpha), \mathrm{MnO}(\mathrm{Mn} K \alpha), \mathrm{MgO}$ $(\mathrm{MgK} \alpha)$ and wollastonite $(\mathrm{CaK} \alpha)$. The $\mathrm{Cr}_{2} \mathrm{O}_{3}$ content was corrected for $\mathrm{V} K \beta$ interference. The ZAF method was used for the matrix correction.

The samples used in the present study were collected from metamorphosed manganese deposits in Japan: six samples (F1, F2, F3, F4, F5, and F6) from the Fujii mine (Fukui), one sample (H1) from Hokkejino (Kyoto), and dark-green garnet separates (Y1) from the Yamato mine (Kagoshima). Samples F1 and H1 are tephroiterhodonite ores that sporadically contain green to colorless garnet. Samples F2, F3, F4. and F5 are rhodonite ores, and green to colorless garnet in these samples occurs in rhodonite-quartz veinlets. Sample F6 is a Mn-rich calcsilicate rock composed mainly of colorless garnet and diopside. Momoiite occurs in samples F1, F2, F3, F5. and $\mathrm{H} 1$, whereas Mn-rich goldmanite occurs in samples F4, F5. and Y1 (Table 1).

Momoiite in F1 occurs as up to $200 \mu \mathrm{m}$ bright green crystals with $\{110\}$ plane (Fig. 1a). F1 sample also contains garnet aggregates composed of bright green momoiite and colorless to pale-green $\mathrm{V}$-bearing spessartine. The two compositional domains in the aggregates are in contact with each other with a sharp boundary (Fig. 1b). Momoiite in F1 sample is optically isotropic, but associated V-bearing spessartine shows weak birefringence. Similar association of optically isotropic momoiite and anisotropic V-bearing spessartine is observed in the Hokkejino sample (H1). In contrast, green garnet in sample F3 lacks compositional gap between V-rich spessartine and V-poor momoiite (Fig. 2), and both of them show weak birefringence.

The analyzed garnet crystals are solid-solutions among the four end-members Grs, Sps, Gdm and Mom, and the other end-member contents are less than $10 \mathrm{~mol} \%$ (Table 1). Therefore, our dataset includes (1) Sps-Grs binary solid-solutions in sample F6, and (2) Sps-Gdm-Mom ternary solid-solutions for V-bearing garnet in the other samples. The latter solid-solutions can be treated as solid-solution series between Sps and Mn-rich Gdm, with the maximum $\mathrm{Mn}_{3} \mathrm{~V}_{2} \mathrm{Si}_{3} \mathrm{O}_{12}$ content of $\sim 40 \mathrm{~mol} \%$ (Fig. 2).

\section{EXPERIMENTAL METHODS}

\section{Single-crystal X-ray diffraction}

A single crystal of momoiite $(0.20 \times 0.20 \times 0.15 \mathrm{~mm})$ was extracted from sample F1 (Fig. 1a). The diffraction data of this momoiite crystal were collected at room temperature with graphite-monochromated $\mathrm{MoK \alpha} \mathrm{X}$-radia- 
Table 1. Electron microprobe analyses of garnet

\begin{tabular}{|c|c|c|c|c|c|c|c|c|c|c|}
\hline $\begin{array}{l}\text { Mineral } \\
\text { Sample }\end{array}$ & $\begin{array}{l}\text { Sps } \\
\mathrm{H} 1\end{array}$ & $\begin{array}{l}\text { Sps } \\
\text { F1 }\end{array}$ & $\begin{array}{c}\text { Mom } \\
\text { H1 }\end{array}$ & $\begin{array}{c}\text { Mom } \\
\text { F1 }\end{array}$ & $\begin{array}{c}\text { Mom } \\
\text { F2 }\end{array}$ & $\begin{array}{c}\text { Mom } \\
\text { F3 }\end{array}$ & $\begin{array}{l}\text { Mom } \\
\text { F5 }\end{array}$ & $\begin{array}{c}\text { Gdm } \\
\text { F4 }\end{array}$ & $\begin{array}{c}\text { Gdm } \\
\text { F5 }\end{array}$ & $\begin{array}{c}\text { Gdm } \\
\text { Y1 }\end{array}$ \\
\hline $\mathrm{SiO}_{2}$ & 37.56 & 36.56 & 34.53 & 35.64 & 35.79 & 33.85 & 33.79 & 35.48 & 34.64 & 34.13 \\
\hline $\mathrm{TiO}_{2}$ & 0.12 & 0.06 & 0.67 & 0.11 & 1.14 & 0.94 & 1.85 & 0.00 & 0.39 & 0.01 \\
\hline $\mathrm{Al}_{2} \mathrm{O}_{3}$ & 20.60 & 16.41 & 6.41 & 4.95 & 7.90 & 5.30 & 5.09 & 2.07 & 5.56 & 2.55 \\
\hline $\mathrm{Cr}_{2} \mathrm{O}_{3}$ & 0.09 & 0.09 & 1.58 & 0.66 & 0.00 & 0.00 & 0.00 & 0.03 & 0.00 & 0.00 \\
\hline $\mathrm{V}_{2} \mathrm{O}_{3}$ & 0.45 & 6.48 & 16.96 & 20.93 & 16.34 & 19.48 & 19.55 & 25.99 & 20.76 & 24.90 \\
\hline $\mathrm{FeO}^{*}$ & 0.16 & 0.04 & 0.13 & 0.65 & 0.29 & 0.21 & 0.03 & 0.07 & 0.15 & 0.75 \\
\hline $\mathrm{MnO}$ & 37.40 & 37.27 & 26.45 & 23.34 & 30.66 & 28.68 & 26.41 & 12.94 & 15.61 & 11.14 \\
\hline $\mathrm{MgO}$ & 0.38 & 0.11 & 0.31 & 0.11 & 0.23 & 0.17 & 0.28 & 0.03 & 0.17 & 0.05 \\
\hline $\mathrm{CaO}$ & 3.85 & 4.27 & 12.21 & 14.19 & 7.99 & 9.39 & 11.51 & 23.03 & 21.35 & 24.36 \\
\hline Total & 100.61 & 101.29 & 99.25 & 100.55 & 100.34 & 98.02 & 98.51 & 99.64 & 98.63 & 97.89 \\
\hline $\mathrm{O}$ & 12.05 & 12.01 & 11.97 & 12.00 & 12.07 & 12.00 & 12.02 & 11.99 & 11.94 & 11.94 \\
\hline $\mathrm{Si}$ & 3.04 & 3.00 & 2.95 & 3.01 & 3.03 & 2.96 & 2.93 & 3.00 & 2.93 & 2.92 \\
\hline $\mathrm{Ti}$ & 0.01 & 0.00 & 0.05 & 0.01 & 0.09 & 0.08 & 0.15 & 0.00 & 0.03 & 0.00 \\
\hline $\mathrm{Al}$ & 1.96 & 1.59 & 0.65 & 0.49 & 0.79 & 0.55 & 0.52 & 0.21 & 0.55 & 0.26 \\
\hline $\mathrm{Cr}$ & 0.01 & 0.01 & 0.11 & 0.04 & 0.00 & 0.00 & 0.00 & 0.00 & 0.00 & 0.00 \\
\hline $\mathrm{V}^{3+}$ & 0.03 & 0.43 & 1.16 & 1.42 & 1.11 & 1.37 & 1.36 & 1.76 & 1.41 & 1.71 \\
\hline $\mathrm{Fe}^{3+}$ & 0.00 & 0.00 & 0.01 & 0.00 & 0.00 & 0.00 & 0.00 & 0.00 & 0.01 & 0.05 \\
\hline $\mathrm{Fe}^{2+}$ & 0.01 & 0.00 & 0.00 & 0.05 & 0.02 & 0.01 & 0.00 & 0.00 & 0.00 & 0.00 \\
\hline $\mathrm{Mn}$ & 2.56 & 2.59 & 1.91 & 1.67 & 2.20 & 2.13 & 1.94 & 0.93 & 1.12 & 0.81 \\
\hline $\mathrm{Mg}$ & 0.05 & 0.01 & 0.04 & 0.01 & 0.03 & 0.02 & 0.04 & 0.00 & 0.02 & 0.01 \\
\hline $\mathrm{Ca}$ & 0.33 & 0.38 & 1.12 & 1.29 & 0.73 & 0.88 & 1.07 & 2.09 & 1.93 & 2.24 \\
\hline Sum & 8.00 & 8.00 & 8.00 & 8.00 & 8.00 & 8.00 & 8.00 & 8.00 & 8.00 & 8.00 \\
\hline $\mathrm{Mn} /(\mathrm{Mn}+\mathrm{Ca})$ & a) 0.88 & 0.87 & 0.63 & 0.57 & 0.75 & 0.71 & 0.64 & 0.31 & 0.37 & 0.27 \\
\hline $\mathrm{V} /(\mathrm{V}+\mathrm{Al})$ & 0.01 & 0.21 & 0.64 & 0.74 & 0.58 & 0.71 & 0.72 & 0.90 & 0.72 & 0.87 \\
\hline
\end{tabular}

${ }^{*}$ All $\mathrm{Fe}$ as FeO. Number of atoms was calculated on the basis of 8 total cations, and $\mathrm{Fe}^{3+} / \mathrm{Fe}^{2+}$ was set to be closer to $12 \mathrm{O}$. Gdm, goldmanite; Mom, momoiite; Sps, spessartine.
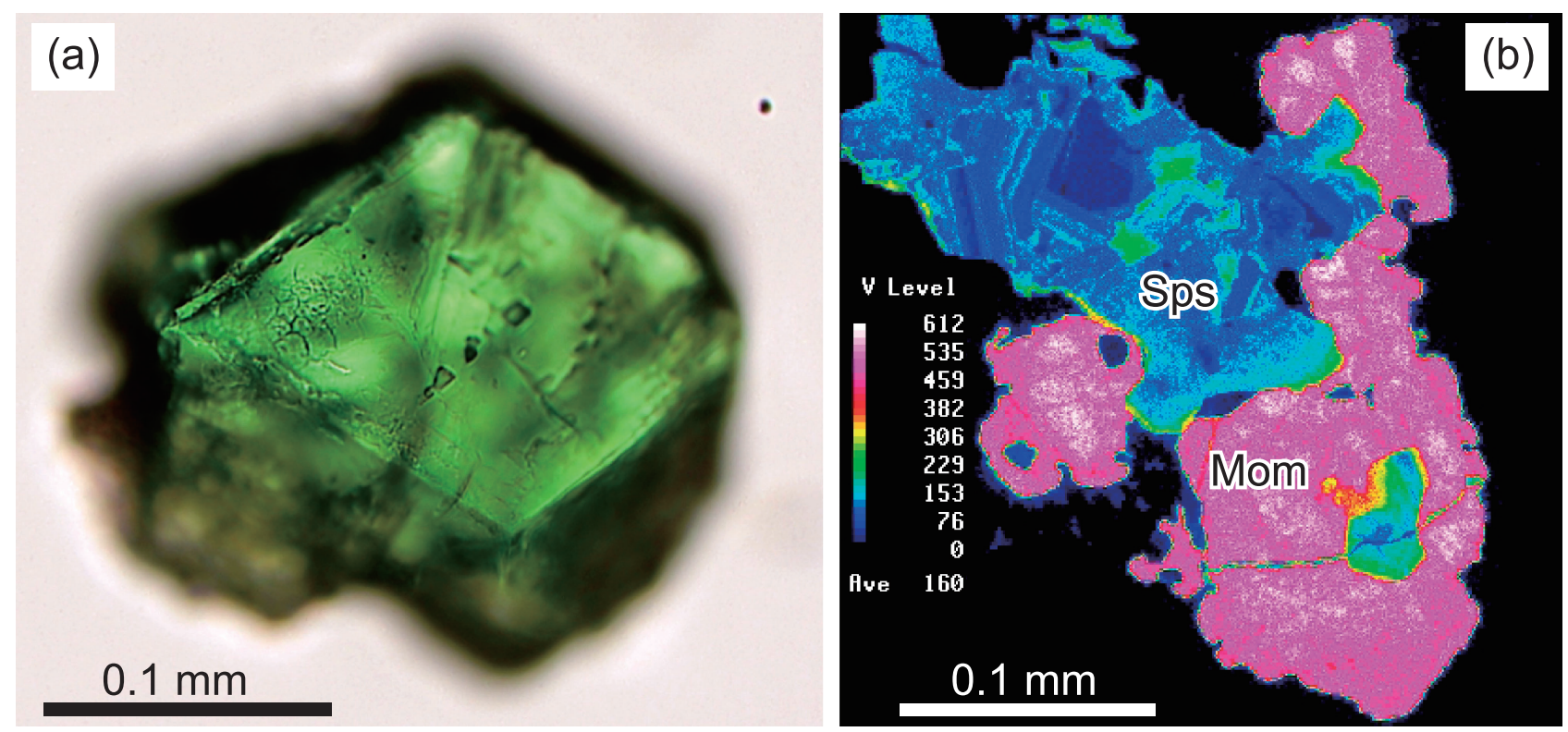

Figure 1. (a) Momoiite crystal extracted from a tephroite-rhodonite ore (F1) from the Fujii mine. This crystal was used for single-crystal Xray diffraction study. (b) Vanadium (VKa) map of momoiite (Mom) and V-bearing spessartine (Sps) aggregate in F1.

tion $(\lambda=0.71073 \AA)$ using a Bruker SMART APEX II CCD diffractometer installed at Shimane University. Preliminary lattice parameters and an orientation matrix were obtained from three sets of frames and refined during the integration process of the intensity data. Diffraction data were collected with $\omega$ scans with different $\varphi$ settings $(\varphi-\omega$ 


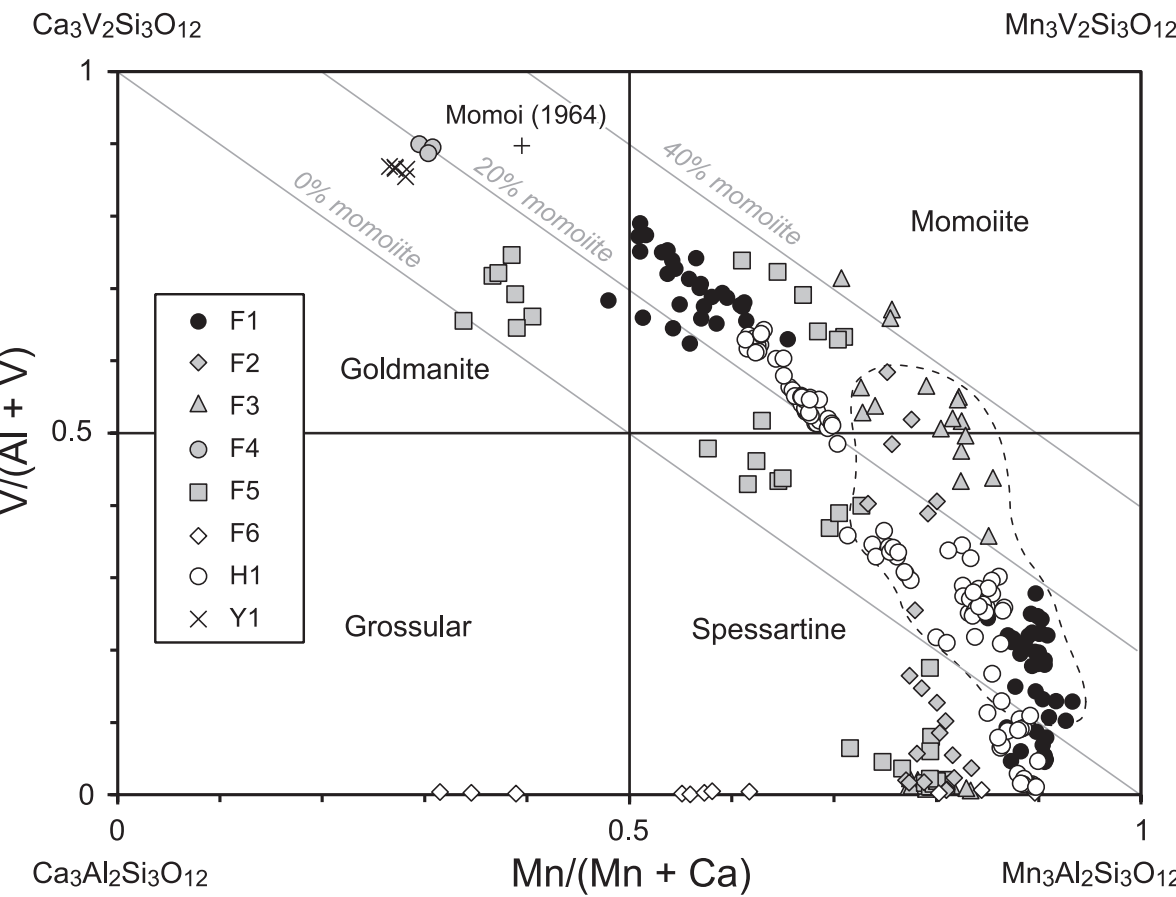

Figure 2. Chemical composition of garnet from the Fujii mine (F1 to F6), Hokkejino (H1) and Yamato mine (Y1) plotted on the $\mathrm{Mn} /(\mathrm{Mn}+$ $\mathrm{Ca})$ versus $\mathrm{V} /(\mathrm{V}+\mathrm{Al})$ plane. Wet chemical analysis of the Yamato mine garnet (Momoi, 1964) is also plotted. Compositional range of optically anisotropic garnet is indicated by dashed line.

scan) (Bruker, 1999). Data were processed using SAINT (Bruker, 1999). An empirical absorption correction using SADABS (Sheldrick, 1996) was applied. Structural refinement was performed using the program SHELXL97 (Sheldrick, 2008). Scattering factors for neutral atoms were employed. At the primary stage population of $\mathrm{Si}$ at the $\mathrm{Z}$ site was refined. However, this site turned out to be fully occupied within standard deviation. Thus, the site occupancy at this site was fixed at 1.0. The site occupancies of the $\mathrm{X}$ and $\mathrm{Y}$ sites were refined with $\mathrm{Mn}$ versus $\mathrm{Ca}$, and $\mathrm{V}$ versus $\mathrm{Al}$, respectively.

\section{Raman spectroscopy}

Non-polarized micro-Raman measurements of garnet crystals in thin sections were performed at ambient conditions $\left(22 \pm 1{ }^{\circ} \mathrm{C}\right)$. Raman spectra were recorded using a Thermo Nicolet Almega XR instrument (at Nagoya University) equipped with a $532 \mathrm{~nm} \mathrm{Nd}$-YAG laser, a 2400 lines/mm grating monochromator, a Peltier-cooled CCD detector $(256 \times 1024$ pixels $)$ and an Olympus BX51 confocal microscope. The objective is an Olympus Mplan$\mathrm{BD} 100 \mathrm{X}(\mathrm{NA}=0.9)$. The spectral resolution is about 1.2 $\mathrm{cm}^{-1}$. The monochromator was calibrated using a plasma line from the Ne lamp, and the accuracy of the Raman frequency shifts was checked by measurement of the $520.3 \mathrm{~cm}^{-1}$ band of a silicon wafer.

Factor group analysis predicts that the garnet structure with $I a \overline{3} d$ symmetry has 25 Raman active vibration modes: $3 A_{1 \mathrm{~g}}+8 E_{\mathrm{g}}+14 T_{2 \mathrm{~g}}$ (Moore et al., 1971). For the common silicate garnet end-members, frequencies and symmetry assignments of the expected 25 Raman modes have been determined by polarized Raman measurements (Hofmeister and Chopelas, 1991; Kolesov and Geiger, 1998). Peak assignments in our non-polarized spectra were carried out on the basis of well-established spessartine spectrum.

\section{RESULTS}

\section{Single-crystal $\mathrm{X}$-ray diffraction}

Crystallographic data and refinement parameters are summarized in Table 2. Deviation of symmetry was carefully considered. Special attention was paid to the significant intensity differences between symmetrically equivalent reflections and the diffraction intensity detected from Ia $\overline{3} d$-forbidden reflections. As a result of careful consideration, the $I a \overline{3} d$ space group symmetry was applied to the structural analysis. It is also supported by the isotropic optical property of momoiite in F1 sample.

Structure refinement converged at $R_{1}$ values of $1.45 \%$. The refined atomic positions and atomic displacement parameters, and site occupancies are listed in Table 3. Selected interatomic distances are listed in Table 4. The structural formula of silicate garnet is ${ }^{\mathrm{VIII}} \mathrm{X}_{3}{ }^{\mathrm{VI}} \mathrm{Y}_{2} \mathrm{Si}_{3} \mathrm{O}_{12}$ $(Z=8)$. The structure consists of alternating $\mathrm{SiO}_{4}$-tetrahedra and $\mathrm{YO}_{6}$-octahedra, which share corners to form three-dimensional framework. Cavities in this framework are enclosed by the eight-coordinated $\mathrm{X}$ site forming a 
Table 2. Experimental details of the single-crystal X-ray diffraction analysis of momoiite crystal

\begin{tabular}{llll}
\hline Crystal size $(\mathrm{mm})$ & $0.20 \times 0.20 \times 0.15$ & Space group & $\operatorname{Ia} \overline{3} d(\mathrm{~A}-230)$ \\
Unit-cell dimensions $(\AA)$ & $a=11.8745(7)$ & Volume $\left(\AA^{3}\right)$ & $V=1674.35(2)$ \\
$Z$ & 8 & $\mu\left(\mathrm{mm}^{-1}\right)$ & 5.56 \\
$D_{\text {calc }}\left(\mathrm{g} / \mathrm{cm}^{3}\right)$ & 4.06 & Collected reflections & 5398 \\
$\theta_{\min }-\theta_{\max }\left({ }^{\circ}\right)$ & $4.2-31.2$ & Unique reflections & 233 \\
Index ranges & $-17 \leq h \leq 16,-8 \leq k \leq 17,-16 \leq l \leq 16$ & $R_{\text {int }}$ & 0.0127 \\
$R_{1}$ & 0.0145 & $R_{\sigma}$ & 0.0047 \\
$w R_{2}$ & 0.0460 & No. of parameters & 19 \\
Weighting scheme & $w=1 /\left[\sigma^{2}\left(F_{\mathrm{o}}^{2}\right)+(0.0203 P)^{2}+1.75 P\right]$ & $\Delta \rho_{\max }\left(\mathrm{e} \AA^{-3}\right)$ & 0.29 at $0.70 \AA$ from $\mathrm{O}$ \\
& & $\Delta \rho_{\min }\left(\mathrm{e} \AA^{-3}\right)$ & -0.25 at $0 \AA$ from Y \\
\hline
\end{tabular}

${ }^{*}$ The function of the weighting scheme is $w=1 /\left[\sigma^{2}\left(F_{\mathrm{o}}^{2}\right)+(a \cdot P)^{2}+b \cdot P\right]$, where $P=\left[\operatorname{Max}\left(F_{\mathrm{o}}^{2}, 0\right)+2 F_{\mathrm{c}}{ }^{2}\right] / 3$, and the parameters $a$ and $b$ are chosen to minimize the differences in the variances for reflections in different ranges of intensity and diffraction angle.

Table 3. Atomic positions, atomic displacement parameters $\left(\AA^{2}\right)$, and site occupancies of momoiite

\begin{tabular}{lcccc}
\hline & $\mathrm{X}$ cation & Y cation & $\mathrm{Si}$ & Oxygen \\
\hline$x$ & $1 / 8$ & 0 & $3 / 8$ & $0.03709(7)$ \\
$y$ & 0 & 0 & 0 & $0.04903(6)$ \\
$z$ & $1 / 4$ & 0 & $1 / 4$ & $0.65512(6)$ \\
Occupancy & $\mathrm{Mn}_{0.588(10) \mathrm{Ca} 0.412}$ & $\mathrm{~V}_{0.731(7) \mathrm{Al}_{0.269}}$ & $\mathrm{Si}_{1.0}(\mathrm{fix})$ & $\mathrm{O}_{1.0}(\mathrm{fix})$ \\
$U_{11}$ & $0.0059(2)$ & $0.0054(2)$ & $0.0071(3)$ & $0.0109(4)$ \\
$U_{22}$ & $0.01132(18)$ & $0.0054(2)$ & $0.0060(2)$ & $0.0087(4)$ \\
$U_{33}$ & $0.01132(18)$ & $0.0054(2)$ & $0.0060(2)$ & $0.0072(4)$ \\
$U_{23}$ & $0.00255(12)$ & $0.00003(8)$ & 0 & $0.0005(3)$ \\
$U_{13}$ & 0 & $0.00003(8)$ & 0 & $-0.0010(3)$ \\
$U_{12}$ & 0 & $0.00003(8)$ & 0 & $0.0013(3)$ \\
$U_{\mathrm{eq}}$ & $0.00950(17)$ & $0.0054(2)$ & $0.0064(2)$ & $0.0089(2)$ \\
\hline
\end{tabular}

Table 4. Selected bond distances of momoiite

\begin{tabular}{ll}
\hline X-O2 $(\times 4)$ & $2.3049(8)$ \\
X-O4 $(\times 4)$ & $2.4529(7)$ \\
Mean & 2.3789 \\
& \\
Y-O $(\times 6)$ & $1.9814(7)$ \\
Shared O-O edge & $2.8004(11)$ \\
Unshared O-O edge & $2.8038(12)$ \\
& \\
Si-O $(\times 4)$ & $1.6426(8)$ \\
Shared O-O edge & $2.5364(11)$ \\
Unshared O-O edge & $2.7523(11)$ \\
Angle variance* & 43.29 \\
\hline
\end{tabular}

* Defined by Robinson et al. (1971).

triangular dodecahedron (Novak and Gibbs, 1971). The $\mathrm{X}-\mathrm{O}$ distances have the two different bond distances. In the garnet structure, the four shorter distance often represented as $\mathrm{X}-\mathrm{O} 2$ and the four longer one as $\mathrm{X}-\mathrm{O} 4$. The refined site occupancies at the $\mathrm{X}$ and $\mathrm{Y}$ sites were $\mathrm{Mn}_{0.592(10)} \mathrm{Ca}_{0.408}$ and $\mathrm{V}_{0.733(7)} \mathrm{Al}_{0.267}$, respectively. The structural formula is represented as ${ }^{\mathrm{X}}\left(\mathrm{Mn}_{1.763} \mathrm{Ca}_{1.237}\right)_{\Sigma 3.000}$ ${ }^{\mathrm{Y}}\left(\mathrm{V}_{1.461} \mathrm{Al}_{0.539}\right)_{\Sigma 2.000}{ }^{\mathrm{Z}} \mathrm{Si}_{3} \mathrm{O}_{12}$.

\section{Raman spectroscopy}

Raman spectra of the Sps-Mn-rich Gdm solid-solution series are shown in Figure 3. V-rich garnet generally shows broader spectra, which are characteristic of intermediate solid-solutions and generally caused by the local distortions in the lattice at sites containing different sizes and masses of cations (Hofmeister and Chopelas, 1991). Raman spectra of this solid-solution series have a characteristic set of the three strong $A_{1 \mathrm{~g}}$ bands near 903-880 $\mathrm{cm}^{-1}\left[\mathrm{Si}-\mathrm{O}\right.$ stretching mode: $\left.(\mathrm{Si}-\mathrm{O})_{\mathrm{str}}\right]$ and $551-518 \mathrm{~cm}^{-1}$ [O-Si-O bending mode: $\left.(\mathrm{O}-\mathrm{Si}-\mathrm{O})_{\text {bend }}\right]$ and $363-352 \mathrm{~cm}^{-1}$ $\left[\mathrm{SiO}_{4}\right.$ rotation: $\left.\mathrm{R}\left(\mathrm{SiO}_{4}\right)\right]$. Less strong peaks are observed in the $(\mathrm{Si}-\mathrm{O})_{\text {str }}$ region of $1027-979, \sim 847,844-817$, in the $(\mathrm{O}-\mathrm{Si}-\mathrm{O})_{\text {bend }}$ region of $631-610,501-489,473-444$, and in the low wavenumber region of $230-222 \mathrm{~cm}^{-1}[\mathrm{X}$ cation translation: $\left.\mathrm{T}\left(\mathrm{X}^{2+}\right), T_{2 \mathrm{~g}}\right]$ and $173-155 \mathrm{~cm}^{-1}\left[\mathrm{SiO}_{4}\right.$ translation: $\mathrm{T}\left(\mathrm{SiO}_{4}\right), E_{\mathrm{g}}+T_{2 \mathrm{~g}}$ ]. The two strong peaks $\left[A_{1 \mathrm{~g}},(\mathrm{Si}-\mathrm{O})_{\text {str }}\right]$ and $\left[A_{1 \mathrm{~g}},(\mathrm{O}-\mathrm{Si}-\mathrm{O})_{\text {bend }}\right]$ and the concomitant less strong peaks systematically shift towards lower frequencies with increasing $\mathrm{V} /(\mathrm{V}+\mathrm{Al})$ and decreasing $\mathrm{Mn} /(\mathrm{Mn}+\mathrm{Ca})$ values. On the other hand, $\mathrm{R}\left(\mathrm{SiO}_{4}\right)$ and $\mathrm{T}\left(\mathrm{X}^{2+}\right)$ peak positions shift towards higher frequencies 


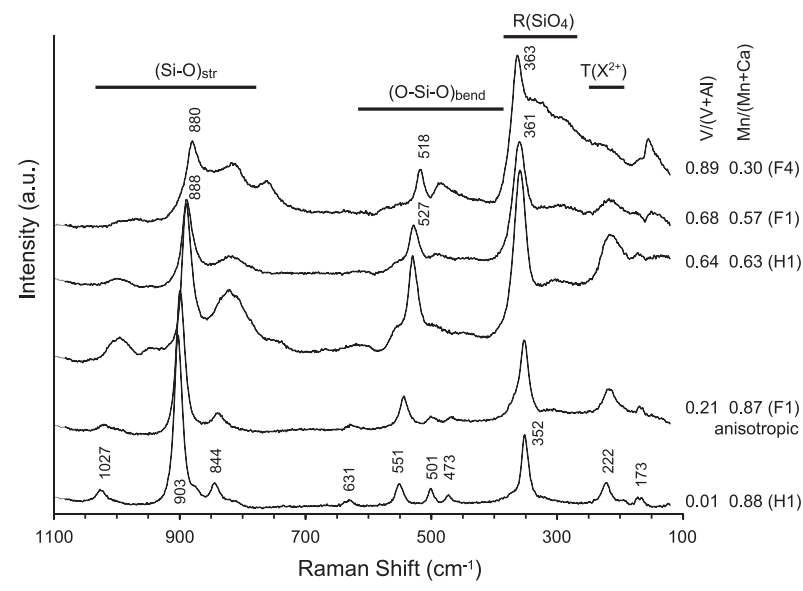

Figure 3. Representative Raman spectra of spessartine, V-bearing spessartine, momoiite solid-solutions and Mn-rich goldmanite.

with the same compositional trend (Figs. 3 and 4). Although symmetry reduction leads to breakdown of the selection rule, optically anisotropic V-bearing spessartine does not show distinct spectral features (Fig. 3).

\section{DISCUSSION}

\section{Crystal chemistry of momoiite}

The variation of unit-cell parameter of silicate garnet is governed by the cation distributions at both $\mathrm{X}$ and $\mathrm{Y}$ sites (Novak and Gibbs, 1971). The refined site occupancies of the $\mathrm{X}$ and $\mathrm{Y}$ sites in momoiite are $\mathrm{Mn}_{0.588(10)}^{2+} \mathrm{Ca}_{0.412}$ and $\mathrm{V}_{0.731(7)}^{3+} \mathrm{Al}_{0.269}$, respectively. The unit-cell parameter of our studied momoiite was $11.8745(7) \AA$, which is longer than for synthetic spessartine, $\mathrm{Mn}_{3} \mathrm{Al}_{2} \mathrm{Si}_{3} \mathrm{O}_{12}$ (11.615$11.619 \AA$ : Geiger and Armbruster, 1997; Rodehorst et al., 2002) and shorter than for synthetic goldmanite, $\mathrm{Ca}_{3} \mathrm{~V}_{2}^{3+} \mathrm{Si}_{3} \mathrm{O}_{12}$ (12.079-12.089 $\AA$ : Righter et al., 2011) (Fig. 5). Furthermore, by using the mathematical equation to estimate the unit-cell parameter for silicate garnet proposed by Langley and Sturgeon (1979), the $a$-dimension is estimated as $11.823 \AA$ in end-member momoiite, $\mathrm{Mn}_{3}^{2+} \mathrm{V}_{2}^{3+} \mathrm{Si}_{3} \mathrm{O}_{12}$.

Variation of $\langle\mathrm{X}-\mathrm{O}>$ and $<\mathrm{Y}-\mathrm{O}>$ is governed by the cation distribution at each site. $\langle\mathrm{X}-\mathrm{O}>$ of momoiite $(2.3789 \AA)$ is approximately intermediate in distance between those observed in synthetic grossular and spessartine $(\mathrm{Ca}-\mathrm{O}=2.40-2.41 \AA$ in Grs by Hazen and Finger, 1978; Ganguly et al. 1993; Geiger and Armbruster, 1997, $\mathrm{Mn}^{2+}$ $\mathrm{O}=2.32-2.33 \AA$ in Sps by Geiger and Armbruster, 1997; Rodehorst et al., 2002). The Y-O distance of momoiite, 1.9814(7) $\AA$, is longer than that of synthetic spessartine $(\mathrm{Al}-\mathrm{O}=\sim 1.90 \AA)$ and shorter than that in synthetic goldmanite $\left(\mathrm{V}^{3+}-\mathrm{O}=\sim 2.02 \AA\right.$ : Righter et al., 2011).
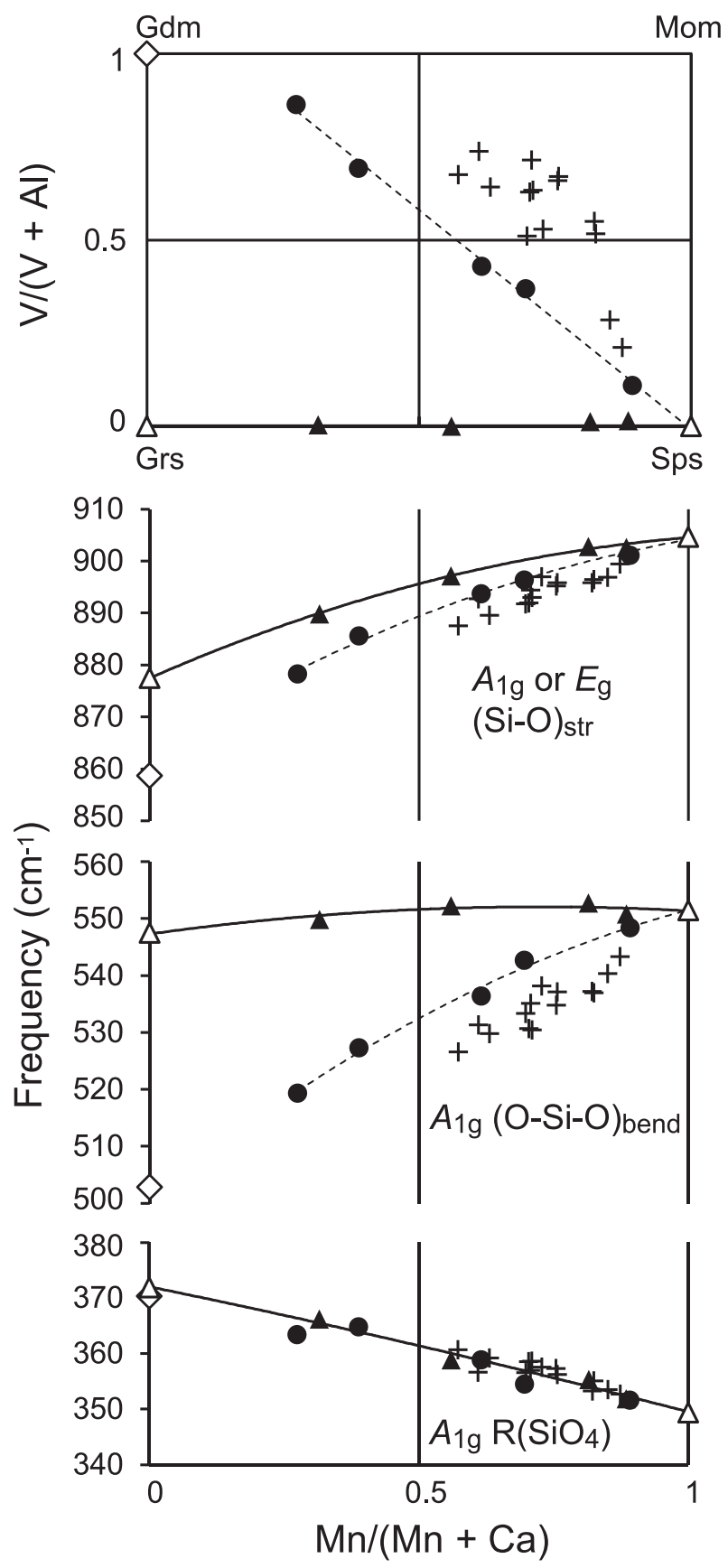

Figure 4. Correlation plots between frequency of the three intense Raman peaks and garnet compositions in the spessartine (Sps), grossular (Grs), goldmanite (Gdm) and momoiite (Mom) system. Dataset is classified into binary Sps-Grs solid-solutions (solid triangles), pseudo-binary $\mathrm{Sps}_{-} \mathrm{Gdm}_{85} \mathrm{Mom}_{15}$ solid-solutions (solid circles), and Sps-Gdm-Mom solid-solutions with higher Mom/Gdm (pluses). End-member Sps and Grs (open triangles) from Kolesov and Geiger (1998) and synthetic endmember Gdm (open diamond) in RRUFF (http://rruff.info/) are also plotted. Regression curves for Sps-Grs and Sps-Gdm 85 Mom $_{15}$ solid-solutions are shown by solid and dashed lines, respectively. 


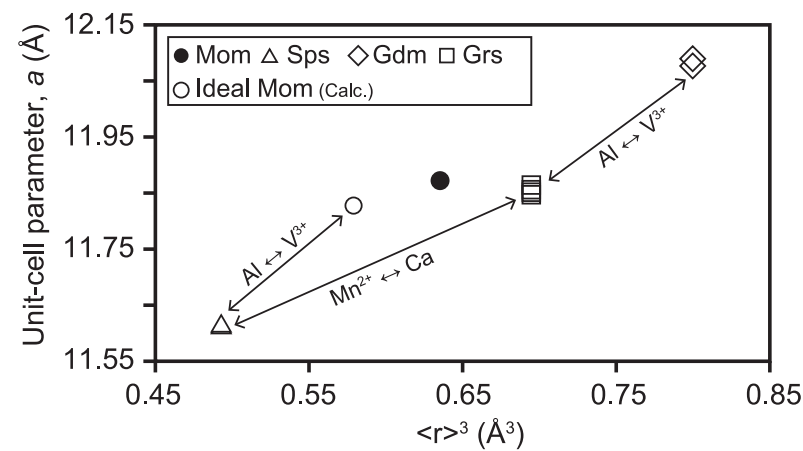

Figure 5. Variations of unit-cell parameter, $a(\AA)$, with respect to the cubed mean radius, $<r>^{3}\left(\AA^{3}\right)$, of the non-tetrahedral cations defined by Novak and Gibbs (1971). Closed circle represents momoiite (Mom: this study), open squares synthetic grossular (Grs: Hazen and Finger, 1978; Ganguly et al. 1993; Geiger and Armbruster, 1997; Rodehorst et al., 2002), open triangles synthetic spessartine (Sps: Geiger and Armbruster, 1997; Rodehorst et al., 2002), and open diamonds synthetic goldmanite (Gdm: Righter et al., 2011). Open circle represents ideal end-member momoiite calculated after Langley and Sturgeon (1979). Standard deviation $(1 \sigma)$ are smaller than the symbol size.

For further understanding of the garnet structure, the cation-cation repulsion across the shared edge of polyhedra should be considered. Pauling (1929) stated in his third rule that the shared edges and particularly common faces between two anion polyhedra decrease the stability of an ionic structure because the shared edges and faces place cations in closer proximity to each other, so that cation-cation electrostatic repulsion is increased. Its significance for the garnet structure is summarized by Nakatsuka (2002). In the garnet structure, the repulsion is mostly pronounced between tetrahedral and dodecahedral cations. The $\mathrm{O}-\mathrm{O}$ edge is shared with the $\mathrm{SiO}_{4}$-tetrahedron and the $\mathrm{XO}_{8}$ dodecahedron (Fig. 6). The shared $\mathrm{SiO}_{4}$ edge with $\mathrm{XO}_{8}$ is known to be shorter than the unshared $\mathrm{SiO}_{4}$ edge in both ugrandite and pyralspite garnets (e.g., Novak and Gibbs, 1971). Thus, in momoiite the shared $\mathrm{SiO}_{4}$ edge with $\mathrm{XO}_{8}$ is $2.536 \AA$ whereas the unshared edge is $2.752 \AA$. It is also known that $\mathrm{SiO}_{4}$-tetrahedron is relatively distorted in the garnet structure (e.g., Born and Zemann, 1964). The shortened O-O shared edges, increase the distance between $\mathrm{Si}$ and $\mathrm{X}$ cations and reduces their repulsion, causing relatively distorted $\mathrm{SiO}_{4}$-tetrahedron in the garnet structure. The $\mathrm{YO}_{6}$ and $\mathrm{XO}_{8}$ polyhedra are also edge-shared (Fig. 6). In case of the structure of pyralspite garnets, the shared edge is shorter than the unshared edge. The principle is same as that shown for the $\mathrm{X}$ and $\mathrm{Z}$ cations mentioned above. However, the length relation between the shared and unshared edges for $\mathrm{XO}_{8}$ and $\mathrm{YO}_{6}$ are reversed in the structure of ugrandite garnets. For instance, the shared edge of

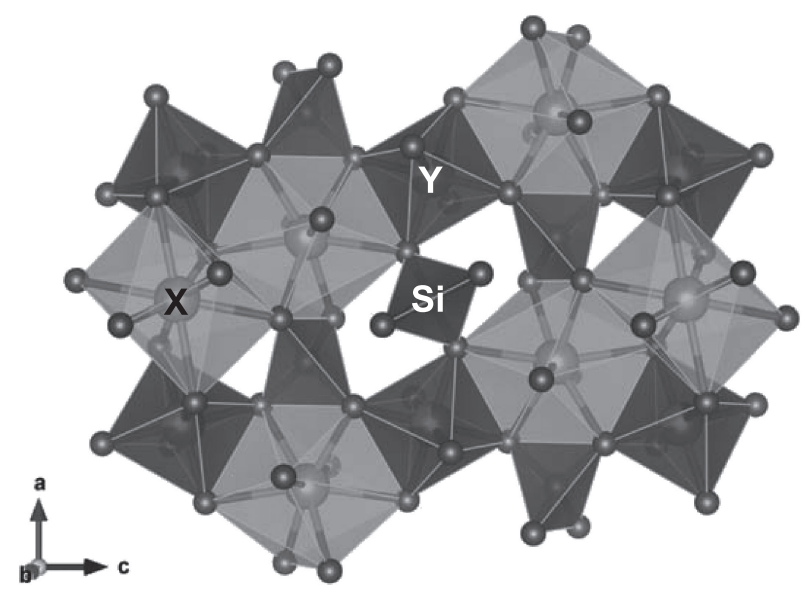

Figure 6. Polyhedral model of the garnet structure drawn with VESTA3 (Momma and Izumi, 2011).

synthetic grossular, 2.75-2.76 $\AA$, is longer than the unshared $\mathrm{YO}_{6}$ edge $(\sim 2.69 \AA$ : Hazen and Finger, 1978; Ganguly et al., 1993; Geiger and Armbruster, 1997). It is explained by the large ionic radius of $\mathrm{Ca}^{2+}(1.12 \AA$ : Shannon, 1976), which reduces repulsion between the $\mathrm{Y}$ and $\mathrm{Z}$ cations (Nakatsuka, 2002). The lengths of shared and unshared $\mathrm{YO}_{6}$ edges in momoiite are 2.800 and $2.804 \AA$, respectively. There are no significant differences reflecting the chemical properties of our studied momoiite crystals having the intermediate composition of pyralspite and ugrandite garnets, ${ }^{\mathrm{X}}\left(\mathrm{Mn}_{1.763} \mathrm{Ca}_{1.237}\right)_{\Sigma 3.000}$

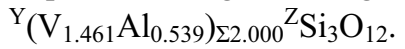

\section{Raman spectroscopy of V-bearing garnet}

Vibration frequencies generally increase with decreasing reduced atomic mass and increasing bond strength (i.e., shorter bond length, smaller ionic radius or unit cell). For solid-solutions among the common silicate garnet endmembers, correlations between Raman frequencies with compositions, and hence ionic radii and masses with some contributions of electronic properties, are well established (Hofmeister and Chopelas, 1991; Kolesov and Geiger, 1998; Pinet and Smith, 1993, 1994; Chopelas, 2005). These results are summarized as follows: (1) lengths of the less compressive $\mathrm{Si}-\mathrm{O}$ bond have no large influences on $(\mathrm{Si}-\mathrm{O})_{\text {str }}$ and $(\mathrm{O}-\mathrm{Si}-\mathrm{O})_{\text {bend }}$ frequency shifts, (2) $(\mathrm{Si}-\mathrm{O})_{\text {str }}$ and $(\mathrm{O}-\mathrm{Si}-\mathrm{O})_{\text {bend }}$ bands shift towards lower frequencies with increasing mean ionic radii of the $\mathrm{X}$ and Y sites, and (3) $\mathrm{R}\left(\mathrm{SiO}_{4}\right), \mathrm{T}\left(\mathrm{SiO}_{4}\right)$, and $\mathrm{T}\left(\mathrm{X}^{2+}\right)$ bands appear to shift towards lower frequencies with increasing mean atomic mass of the $\mathrm{X}$ site.

The effective ionic radii of ${ }^{[8]} \mathrm{Ca}(1.12 \AA)$ and ${ }^{[6]} \mathrm{V}$ $(0.64 \AA)$ are larger than ${ }^{[8]} \mathrm{Mn}^{2+}(0.96 \AA)$ and ${ }^{[6]} \mathrm{Al}(0.535$ 
$\AA$ ), respectively (Shannon, 1976). As discussed above, $\mathrm{X}-\mathrm{O}$ and $\mathrm{Y}-\mathrm{O}$ lengths and lattice constant of momoiite solid-solution are consistent with those expected as an intermediate composition of relevant end-members (Fig. 5). Therefore the observed downward frequency shifts of $(\mathrm{Si}-\mathrm{O})_{\text {str }}$ and $(\mathrm{O}-\mathrm{Si}-\mathrm{O})_{\text {bend }}$ bands from spessartine through momoiite solid-solutions to $\mathrm{Mn}$-rich goldmanite can be explained by increases in mean ionic radii of the $\mathrm{X}$ and $\mathrm{Y}$ sites by the $\mathrm{Mn}-\mathrm{Ca}$ and $\mathrm{Al}-\mathrm{V}$ substitutions, respectively. The $(\mathrm{Si}-\mathrm{O})_{\text {str }}$ bands are strongly dependent both on the $\mathrm{Mn}-\mathrm{Ca}$ and $\mathrm{Al}-\mathrm{V}$ substitutions, whereas the $(\mathrm{O}-\mathrm{Si}-\mathrm{O})_{\text {bend }}$ bands shows grater dependence on the Al-V substitution than the $\mathrm{Mn}-\mathrm{Ca}$ substitution as shown by smaller frequency shifts along the Sps-Grs join (Fig. 4). The frequency data of the $A_{1 \mathrm{~g}}(\mathrm{O}-\mathrm{Si}-\mathrm{O})_{\text {bend }}$ mode (Fig. 4) were empirically regressed to a quadric equation of the two compositional variables:

$$
\begin{aligned}
& (\mathrm{O}-\mathrm{Si}-\mathrm{O})_{\text {bend }}\left(\mathrm{cm}^{-1}\right)=28.3[\mathrm{~V} /(\mathrm{V}+\mathrm{Al})]^{2} \\
& \quad-13.1[\mathrm{Mn} /(\mathrm{Mn}+\mathrm{Ca})]^{2} \\
& \quad+33.7[\mathrm{~V} /(\mathrm{V}+\mathrm{Al})][\mathrm{Mn} /(\mathrm{Mn}+\mathrm{Ca})] \\
& \quad-71.65[\mathrm{~V} /(\mathrm{V}+\mathrm{Al})]+17.08[\mathrm{Mn} /(\mathrm{Mn}+\mathrm{Ca})] \\
& \quad+547.1\left(R^{2}=0.97\right) .
\end{aligned}
$$

This equation implies that frequency shift of the $A_{1 \mathrm{~g}}\left(\mathrm{O}_{-}\right.$ $\mathrm{Si}-\mathrm{O})_{\text {bend }}$ mode along the Sps-Mom join is much smaller than that along the Grs-Gdm join, although there is no assurance to extrapolate this empirical equation to the Sps-Mom join.

The $A_{1 \mathrm{~g}} \mathrm{R}\left(\mathrm{SiO}_{4}\right)$ vibration frequency shows strong correlation with the $\mathrm{Mn} /(\mathrm{Mn}+\mathrm{Ca})$ value and is apparently independent on the $\mathrm{V} /(\mathrm{V}+\mathrm{Al})$ value. The strong correlation between the rotation of $\mathrm{SiO}_{4}$ tetrahedron and the $\mathrm{Mn}$ Ca substitution in the $\mathrm{X}$ site can be explained by the fact that $\mathrm{SiO}_{4}$ tetrahedron shares two edges with $\mathrm{XO}_{8}$-dodecahedra, but only corners with $\mathrm{YO}_{6}$-octahedra (Fig. 6). The lower frequency shifts of $\mathrm{R}\left(\mathrm{SiO}_{4}\right)$ band with increasing $\mathrm{Mn} /(\mathrm{Mn}+\mathrm{Ca})$ are consistent with increasing mean atomic mass and decreasing mean ionic radii in the $\mathrm{X}$ site. The frequency of the $A_{1 \mathrm{~g}} \mathrm{R}\left(\mathrm{SiO}_{4}\right)$ mode for $\mathrm{V}$-free data were regressed to a quadric function of $\mathrm{Mn} /(\mathrm{Mn}+\mathrm{Ca})$ :

$$
\begin{aligned}
& \mathrm{R}\left(\mathrm{SiO}_{4}\right)\left(\mathrm{cm}^{-1}\right)=-2.53[\mathrm{Mn} /(\mathrm{Mn}+\mathrm{Ca})]^{2} \\
& \quad-19.99[\mathrm{Mn} /(\mathrm{Mn}+\mathrm{Ca})]+372.0\left(R^{2}=0.99\right) .
\end{aligned}
$$

V-rich data also fall in this regression curve (Fig. 4). Using the two equations, garnet compositions can be determined from Raman spectra as long as sample compositions within the range of the regression analyses (0-40 $\mathrm{mol} \% \mathrm{Mn}_{3} \mathrm{~V}_{2} \mathrm{Si}_{3} \mathrm{O}_{12}$ content).

\section{CONCLUSIONS}

We report the first single-crystal X-ray diffraction data of momoiite $(\mathrm{Mn}, \mathrm{Ca})_{3}(\mathrm{~V}, \mathrm{Al})_{2} \mathrm{Si}_{3} \mathrm{O}_{12}$. Structural refinement shows that momoiite solid-solution is isostructural to the other common silicate garnets, and its structural features can be understood by the $\mathrm{Mn}-\mathrm{Ca}$ and $\mathrm{Al}-\mathrm{V}$ substitutions in the $\mathrm{X}$ and $\mathrm{Y}$ sites, respectively. Raman spectra of momoiite solid-solutions also show frequency shifts of each band consistent with those expected by the two substitutions. Since the solubility of $\mathrm{Mn}_{3} \mathrm{~V}_{2} \mathrm{Si}_{3} \mathrm{O}_{12}$ into garnet solid-solutions is a potential geobarometer, further comprehensive studies on momoiite solid-solutions with higher $\mathrm{Mn}_{3} \mathrm{~V}_{2} \mathrm{Si}_{3} \mathrm{O}_{12}$ content (40-100 mol\%) are necessary.

\section{ACKNOWLEDGMENTS}

The first author thanks the late Dr. K. Sakurai, A. Hagiwara, and T. Kamiya for providing samples used in this study and Dr. M. Tasaka for her assistance in operation of Bruker SMART APEXII. One of the authors (M.N.) thanks Prof. Armbruster for his comments on crystal chemistry of momoiite. The manuscript is significantly improved by constructive comments from two anonymous reviewers.

\section{REFERENCES}

Bersani, D., Andò, S., Vignola, P., Moltifiori, G., Marino, I.-G., Littici, P.P. and Diella, V. (2009) Micro-Raman spectroscopy as a routine tool for garnet analysis. Spectrochimica Acta Part A: Molecular and Biomolecular Spectroscopy, 73, 484-491.

Born, L. and Zemann, J. (1964) Abstandsberechnungen und gitterenergetische Berechnungen an Granaten. Contributions to Mineralogy and Petrology, 10, 2-23.

Bruker (1999) SMART and SAINT-Plus. Versions 6.01. Bruker AXS Inc., Madison, Wisconsin, USA.

Chopelas, A. (2005) Single crystal Raman spectrum of uvarovite, $\mathrm{Ca}_{3} \mathrm{Cr}_{2} \mathrm{Si}_{3} \mathrm{O}_{12}$. Physics and Chemistry of Minerals, 32, 525530.

Fursenko, B.A. (1983) Synthesis of new high-pressure silicate garnets $\mathrm{Mn}_{3} \mathrm{M}_{2} \mathrm{Si}_{3} \mathrm{O}_{12}(\mathrm{M}=\mathrm{V}, \mathrm{Mn}, \mathrm{Ga})$. Doklady Akaswmii Nuak SSSR, 268, 421-424 (in Russian).

Ganguly, J., Cheng, W. and O’Neill, H.S.C. (1993) Syntheses, volume, and structural changes of garnets in the pyrope-grossular join: Implications for stability and mixing properties. American Mineralogist, 78, 583-593.

Geiger, C.A. and Armbruster, T. (1997) $\mathrm{Mn}_{3} \mathrm{Al}_{2} \mathrm{Si}_{3} \mathrm{O}_{12}$ spessartine and $\mathrm{Ca}_{3} \mathrm{Al}_{2} \mathrm{Si}_{3} \mathrm{O}_{12}$ grossular garnet: Structural dynamic and thermodynamic properties. American Mineralogist, 82, 749747.

Hazen, R.M. and Finger, L.W. (1978) Crystal structures and compressibilities of pyrope and grossular to $60 \mathrm{kbar}$. American Mineralogist, 63, 297-303.

Hofmeister, A.M. and Chopelas, A. (1991) Vibrational spectroscopy of end-member silicate garnets. Physics and Chemistry of Minerals, 17, 503-526. 
Kolesov, B.A. and Geiger, C.A. (1998) Raman spectra of silicate garnets. Physics and Chemistry of Minerals, 25, 142-151.

Langley, R. and Sturgeon, G.D. (1979) Lattice parameters and ionic radii of the oxide and fluoride garnets. Journal of Solid State Chemistry, 30, 79-82.

Matsubara, S., Miyawaki, R., Yokoyama, K., Shigeoka, M., Miyajima, H., Suzuki, Y., Murakami, O. and Ishibashi, T. (2010) Momoiite and nagashimalite from the Tanohata mine, Iwate Prefecture, Japan. Bulletin of the National Museum of Nature and Science Series C, 36, 1-6.

Momma, K. and Izumi, F. (2011) VESTA3 for three-dimensional visualization of crystal, volumetric and morphology data. Journal of Applied Crystallography, 44, 1257-1276.

Momoi, H. (1964) A new vanadium garnet, $(\mathrm{Mn}, \mathrm{Ca})_{3} \mathrm{~V}_{2} \mathrm{Si}_{3} \mathrm{O}_{12}$, from the Yamato mine, Amami Islands, Japan. Memoirs of the Faculty of Science, Kyushu University, Series D, 15, 73-78.

Moore, R.K., White, W.B. and Long, T.V. (1971) Vibrational spectra of the common silicates: I. The garnets. American Mineralogist, 56, 54-71.

Nakatsuka, A. (2002) Significance of the neighboring cation-cation repulsion in garnet structure. Japanese Magazine of Mineralogical and Petrological Sciences, 31, 25-36 (in Japanese with English abstract).

Novak, G.A. and Gibbs, G.V. (1971) The crystal chemistry of the silicate garnets. American Mineralogist, 56, 791-825.

Pauling, L. (1929) The principles determining the structure of complex ionic crystals. Journal of the American Chemical Society, 51, 1010-1026.

Pinet, M. and Smith, D.C. (1993) Raman microspectrometry of garnets $\mathrm{X}_{3} \mathrm{Y}_{2} \mathrm{Si}_{3} \mathrm{O}_{12}: 1$. The natural calcic series uvarovitegrossular-andradite. Schweizerische Mineralogische und Petrographische Mitteilungen, 73, 21-40.

Pinet, M. and Smith, D.C. (1994) Raman microspectrometry of garnets $\mathrm{X}_{3} \mathrm{Y}_{2} \mathrm{Si}_{3} \mathrm{O}_{12}: 2$. The natural alminian series pyropealmandine-spessartine. Schweizerische Mineralogische und Petrographische Mitteilungen, 73, 21-40.

Righter, K., Sutton, S., Danielson, L., Pando, K., Schmidt, G., Yang, H., Berthet, S., Newville, M., Choi, Y., Downs, R.T. and Malavergne, V. (2011) The effect of $f_{\mathrm{O}_{2}}$ on the partitioning and valence of $\mathrm{V}$ and $\mathrm{Cr}$ in garnet/melt pairs and the relation to terrestrial mantle $\mathrm{V}$ and $\mathrm{Cr}$ content. American Mineralogist, 96, 1278-1290.

Robinson, K., Gibbs, G.V. and Ribbe, P.H. (1971) Quadratic elongation: A quantitative measure of distortion in coordination polyhedra. Science, 172, 567-750.

Rodehorst, U., Geiger, C.A. and Armbruster, T. (2002) The crystal structures of grossular and spessartine between 100 and $600 \mathrm{~K}$ and the crystal chemistry of grossular-spessartine solid solutions. American Mineralogist, 87, 542-549.

Shannon, R.D. (1976) Revised effected ionic radii and systematic studies of interatomic distances in halides and chalcogenides. Acta Crystallographica, A32, 751-767.

Sheldrick, G.M. (1996) SADABS. University of Göttingen, Germany.

Sheldrick, G.M. (2008) A short history of SHELX. Acta Crystallographica, A64, 112-122.

Tanaka, H., Endo, S., Minakawa, T., Enami, M., Nishio-Hamane, D., Miura, H. and Hagiwara, A. (2010) Momoiite, $\left(\mathrm{Mn}^{2+}, \mathrm{Ca}\right)_{3}$ $\left(\mathrm{V}^{3+}, \mathrm{Al}_{2} \mathrm{Si}_{3} \mathrm{O}_{12}\right.$, a new manganese vanadium garnet from $\mathrm{Ja}$ pan. Journal of Mineralogical and Petrological Sciences, 105, 92-96.

Manuscript received February 19, 2019

Manuscript accepted June 30, 2019

Published online September 10, 2019

Manuscript handled by M. Satish-Kumar 